\title{
Omalizumabo veiksmingumas gydant sunkią alerginę astmą
}

\author{
EFFECTIVENESS OF OMALIZUMAB IN SEVERE ALLERGIC ASTHMA
}

\section{KRISTINA BIEKŠIENĖ}

LSMU MA Pulmonologijos klinika

Santrauka. Omalizumabas tai veiksmingas pridètinis vaistas sunkiai alerginei astmai gydyti. Gydant omalizumabu, mažèja paūmèjimu dažnis, mažéja ne tik geriamuju, bet ir inhaliuojamuju gliukokortikoidu dozés, gerèja gyvenimo kokybe. Ilgalaikis gydymas omalizumabu yra veiksmingas ir pasižymi palankiu saugumo profiliu, be to, juo galima gydyti ir vaikus.

Reikšminiai žodžiai: anti IgE, omalizumabas, sunki alergine astma.

Summary. Omalizumab is effective for the treatment of severe allergic asthma. Omalizumab decreases the rate of exacerbation, the dose not only of systemic, bet also inhaled gliucocorticoids, increases the quality of life. Long term treatment with omalizumab is efective and safe, besides is the posibillty to treat children.

Key words: anti IgE, omalizumab, severe allergic asthma.

Sunki astma - tai didelè sveikatos priežiūros bei socialinè ir ekonominè problema. Sunkia astma serga iki 5 proc. visų astma sergančių asmenų. Sunki alerginè astma - vienas dažniausių sunkios astmos fenotipų $[1,2]$.

Omalizumabas (Xolair) - tai vaistas, atvèręs biologinès terapijos erą sunkios astmos gydyme. Omalizumabas yra rekombinantinès DNR technologijos būdu išgautas žmogui pritaikytas monokloninis antikūnas. Jis yra pridedamasis vaistas astmos kontrolei gerinti sunkia alergine astma sergantiems pacientams [3].

Omalizumabo klinikinis poveikis buvo plačiai ištirtas atsitiktinių imčių klinikiniuose tyrimuose, kuriuose dalyvavo daugiau nei 3500 sunkia alergine astma sergančių pacientų [4-12] (1 lentelè).

\section{PAŪMÉJIMAI}

Remiantis klinikinių tyrimų duomenimis, gydant omalizumabu, sumažèja sunkių astmos paūmèjimų. Viename iš klinikinių tyrimų, INNOVATE (angl. INvestigation of Omalizumab in Severe Asthma TrEatment), pirminis tikslas buvo kliniškai reikšmingų astmos paūmẻjimų dažnis. I̦ klinikinị tyrimą buvo ittraukti $12-75$ metų pacientai $(n=419)$, sergantys sunkia nekontroliuojama alergine astma. Pacientai

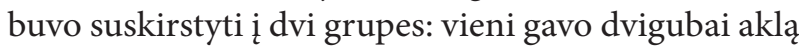
gydymą omalizumabu $(n=209)$, kiti $(n=210)$ - placebą. Gydymo trukmè - 28 savaitès. Studijos rezultatai parode, kad omalizumabo grupeje pacientai 26,2 proc. mažiau patyrè kliniškai reikšmingų astmos paūmè-

1 lentelè. Klinikiniai tyrimai, kuriuose tirtas omalizumabo veiksmingumas gydant sunkią alerginę astmą

\begin{tabular}{|l|c|c|c|l|}
\hline Klinikinis tyrimas & $\begin{array}{l}\text { Visi randomizuoti } \\
\text { pacientai (n) }\end{array}$ & $\begin{array}{l}\text { SAA* sergantys } \\
\text { pacientai, } \mathbf{n} \text { (proc.) }\end{array}$ & $\begin{array}{l}\text { Gydymo trukmé } \\
\text { (sav.) }\end{array}$ & Pirminis tikslas \\
\hline EXTRA [4] & 850 & $850(100)$ & 48 & Paūmèjimų dažnis \\
\hline EXALT [5] & 404 & $404(100)$ & 32 & Atsako dažnis (proc.) \\
\hline INNOVATE [6] & 419 & $419(100)$ & 28 & Paūmèjimu dažnis \\
\hline ETOPA [7, 8] & 312 & $294(94,2)$ & 52 & Paūmèjimų dažnis \\
\hline SOLAR [9] & 405 & $364(89,9)$ & 28 & Paūmèjimų atvejai \\
\hline Studija 008 [8, 10] & 525 & $521(99,6)$ & 28 & Paūmèjimų dažnis \\
\hline Studija 009 [8, 11] & 546 & $537(98,4)$ & $246(100)$ & Paūmèjimų dažnis \\
\hline Studija 011 [12] & 246 & $\mathbf{3 6 3 7}(\mathbf{9 8})$ & $\mathbf{2 8 - 5 2}$ & Daugiausia paūmèjimai \\
\hline Iš viso & $\mathbf{3 7 0 7}$ & & dozes sumažèjimas \\
\hline
\end{tabular}

*SAA -sunki alerginė astma, ^IGK-inhaliuojamieji gliukokortikoidai. 
Vidutinès palaikomosios GGK dozès pokytis po 32 gydymo savaitès lyginant su pradine

Omalizumabas + OAG $(n=59)$
GGK vartojimo pokytis po 32 gydymo savaitès lyginant su pradiniu

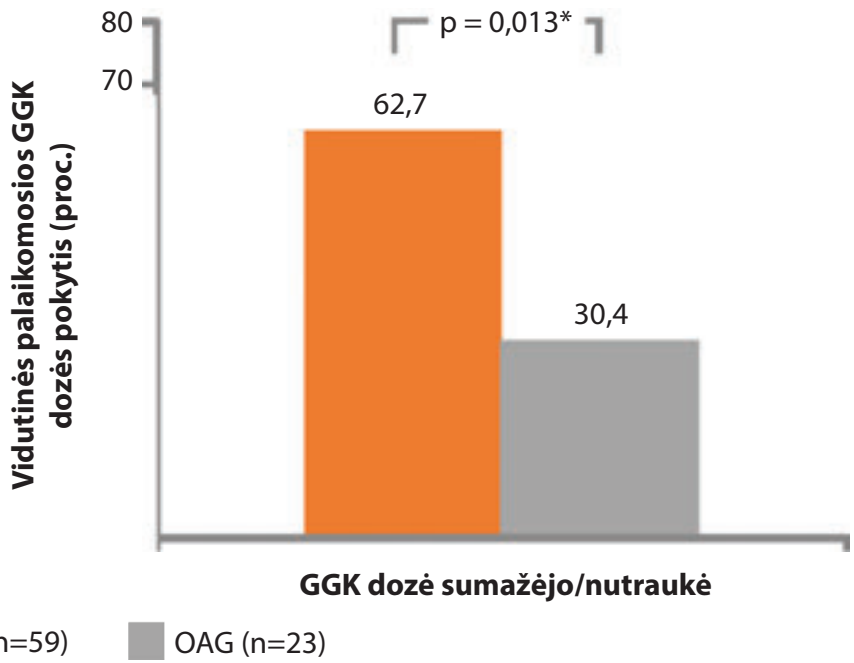

1 pav. Omalizumabas sumažina geriamujų gliukokortikoidụ poreikị sergantiesiems sunkia alergine astma

* $\mathrm{p}=0,013$ (omalizumabas +OAG vs OAG); OAG - optimalus astmos gydymas

jimų nei placebo grupejje $(0,68$ ir 0,91 , atitinkamai $\mathrm{p}=0,042)$. Gydymas omalizumabu 50 proc. sumažino sunkių astmos paūmèjimų dažnị lyginant su placebu $(0,24$ palyginus su $0,48, \mathrm{p}=0,002)$ bei 44 proc. vizitu i skubiosios pagalbos skyrių $(0,24$ palyginus su 0,43 , $\mathrm{p}=0,038$ ). Taip pat omalizumabo grupeje pacientų, $\mathrm{ku}-$ rie pasiekè kliniškai reikšmingą ( $>0,5$ balų) gyvenimo kokybės pagèrèjimą, buvo daugiau nei placebo grupèje (atitinkamai - 61 proc. ir 48 proc.; $\mathrm{p}=0,008$ ) [6].

Bendra klinikinių tyrimų, kuriuose dalyvavo sunkia astma sergantys pacientai, duomenų analizè parodé, kad gydant omalizumabu, astmos paūmèjimų dažnis sumažèjo 38,3 proc. lyginant su placebo grupe $(0,910$ palyginus su 1,474, atitinkamai $\mathrm{p}<0,0001$ ) [13].

\section{GGK IR IGK VARTOJIMAS}

Sunkia astma sergantys pacientai astmos kontrolei pasiekti ir išlaikyti dažnai turi vartoti geriamuosius gliukokortikoidus (GGK), kurie sukelia daug šalutinių poveikių. Siergiejko ir kt. paskelbẻ atsitiktinių imčių tyrimą, kuriame buvo vertinamas omalizumabo, pridèto prie optimalaus astmos gydymo (OAG), poveikis GGK dozès pokyčiams. Pacientai (12-75 metu amžiaus), sergantys sunkia nekontroliuojama alergine astma, 32 savaites buvo gydyti omalizumabu ir OAG $(n=59)$ arba tik OAG $(n=23)$. Studijos rezultatai parodè, kad GGK dozès pokytis buvo reikšmingai didesnis OMA/OAG grupèje nei OAG grupejje ( -45 proc. palyginus su $+18,3$ proc., $\mathrm{p}=0,002)$. OMA/OAG grupeje, 37 pacientai (62,7 proc.) sumažino GGK dozę arba nutraukè jų vartojimą, lyginant su septyniais pacientais $(30,4$ proc.) vartojusiais $\mathrm{OAG}(\mathrm{p}=0,013)$ [14] (1 pav.).

Tačiau gydant omalizumabu, mažèja ne tik GGK, bet ir inhaliuojamųjų (IGK) dozès. Busse ir kt. paskelbė III fazes dvigubai aklą, placebu kontroliuojamą klinikinị tyrimą, kuriame dalyvavo 525 sunkia alergine astma sergantys ir IGK gydomi pacientai. 16 savaičiu buvo skiriama pastovi IGK dozè, o kitas 12 savaičių IGK dozė buvo palaipsniui mažinama. Paskutines keturias gydymo savaites pacientai vartojo mažiausią veiksmingą palaikomąją IGK dozę. Tyrimo rezultatai parodè, kad vidutinė IGK dozė reikšmingai sumažéjo gydant omalizumabu lyginant su placebu (75 proc. palyginus su 50 proc. $\mathrm{p}<0,001)$. Reikšmingai daugiau pacientų omalizumabo grupeje IGK dozę sumažino $\geq 50$ proc. palyginus su placebo grupeje $(72,4$ proc. palyginus su 54,9 proc. $\mathrm{p}<0,001)$. IGK visai nutrauke 106 (39,6 proc.) iš 268 pacientų, gydytų omalizumabu, ir $49(19,1$ proc.) iš 257 placebo grupès $(\mathrm{p}<0,001)$ [10] (2 pav.).

Aštuonių klinikinių omalizumabo tyrimų bendra analizè (išviso 3429 pacientai; 1883 vartojo omalizumabą, 1546 - placebą) rezultatai parodè, kad pacientai, gydyti omalizumabu, buvo labiau linkę nutraukti GK vartojimą arba sumažinti jų dozes nei placebo grupeje (41,8 proc. palyginus su 21,0 proc.) (rizikos santykis (RS) 1,80, 95 proc. pasikliautinasis intervalas (PI), $1,42-2,28)$. Taip pat daugiau pacientų, gydytų omalizumabu, pavyko sumažinti GKK dozę $>50$ proc. nei vartojusiųjų placebą (76 proc. palyginus su 56,0 proc.) (RS 1,34, 95 proc. PI, 1,23-1,46) [15].

\section{ILGALAIKIS OMALIZUMABO POVEIKIS}

Daugelis atsitiktinių imčių klinikinių tyrimų, įrodžiusių omalizumabo klinikinị veiksmingumą, truko iki vienerių metų. Tačiau omalizumabas išsiskiria iš kitų sunkios astmos biologinès terapijos vaistų turimais 


\section{Farmakoterapija}

ilgalaikio gydymo poveikio ir saugumo vertinimo duomenimis. Neseniai paskelbtas klinikinès praktikos tyrimas [16], kurio metu vertintas omalizumabo veiksmingumas ir saugumas gydant sunkia astma sergančius pacientus penkerius metus. Šio tyrimo duomenys parode, kad ilgalaikis gydymas omalizumabu sumažino sveikatos priežiūros išlaidas ( 80 proc. sumažèjo hospitalizacijų, 48,5 proc. - vizitų i skubiosios pagalbos skyrių), 76,7 proc. vartojamų GGK dozę, dèl astmos praleistų pamokų, darbo dienų skaičių, pagerèjo astmos kontrolè, kvejpavimo funkcija. Ilgą laiką vartojamas omalizumabas buvo gerai toleruojamas.

Ledford ir kt. paskelbto klinikinio tyrimo tikslas ivertinti, ar ilgalaikio gydymo omalizumabu veiksmingumas išlieka ir jị nutraukus, bei ištirti, ar toliau tęsiant gydymą omalizumabu išlieka jo poveikis. I tyrimą itraukti pacientai, gydyti omalizumabu apie penkerius metus ( $n=176) .88$ iš jų toliau tęsė gydymą omalizumabu, o kiti 88 nutraukè ir gavo placebą. Nepatyrusių astmos paūmèjimų pacientų buvo daugiau omalizumabo vartojimą tęsusiųjų grupejje ( $\mathrm{n}=59$ (67 proc.)) nei nutraukusiųjų ( $\mathrm{n}=42$ (47,7 proc.). Laikotarpis iki pirmo astmos paūmèjimo buvo ilgesnis ( 3 pav.), simptomų kontrolè geresnè omalizmabo grupèje nei placebo. Ilgalaikis gydymas omalizumabu buvo saugus, o šalutinių reiškinių dažnis nesiskyrè nuo placebo [17]. EXCELS (angl. The Epidemiologic Study of Xolair (omalizumab): Evaluating Clinical Effectiveness and Long-term Safety in Patients with Moderate-to-Severe Asthma) klinikinis tyrimas vertino ilgalaikio gydymo (penkeri metai) omalizumabu galimą poveiki piktybi- nių navikų išsivystymui. Tyrimo rezultatai parode, kad, gydant omalizumabu, piktybinių navikų dažnis omalizumabo ir ne omalizumabo grupèse nesiskyrè [18].

\section{OMALIZUMABAS VAIKŲ AMŽIUJE}

Daliai sunkia alergine astma sergančių vaikų nepavyksta ligos kontroliuoti nepaisant skiriamo gydymo didelèmis IGK dozèmis ir ilgo veikimo $\beta_{2}$-agonistais, neretai gydymą tenka papildyti GGK. Kulus ir kt. paskelbẻ atsitiktinių imčių, dvigubai aklą, placebu kontroliuojamą klinikinị tyrimą, kurio tikslas - įver-

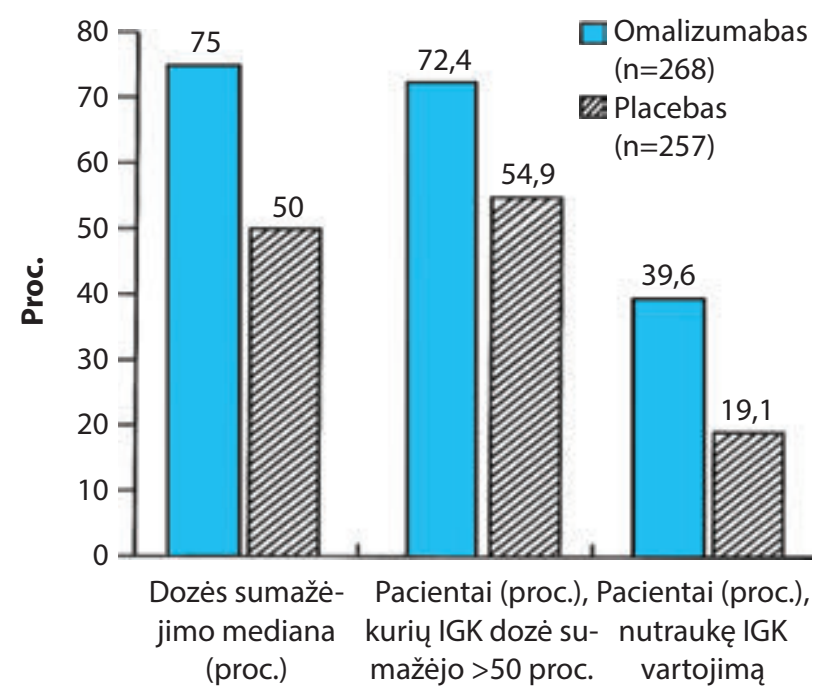

2 pav. Omalizumabas sumažino inhaliuojamuju gliukokortikoidų poreiki

Trumpiniai: IGK - inhaliuojamieji gliukokortikoidai.

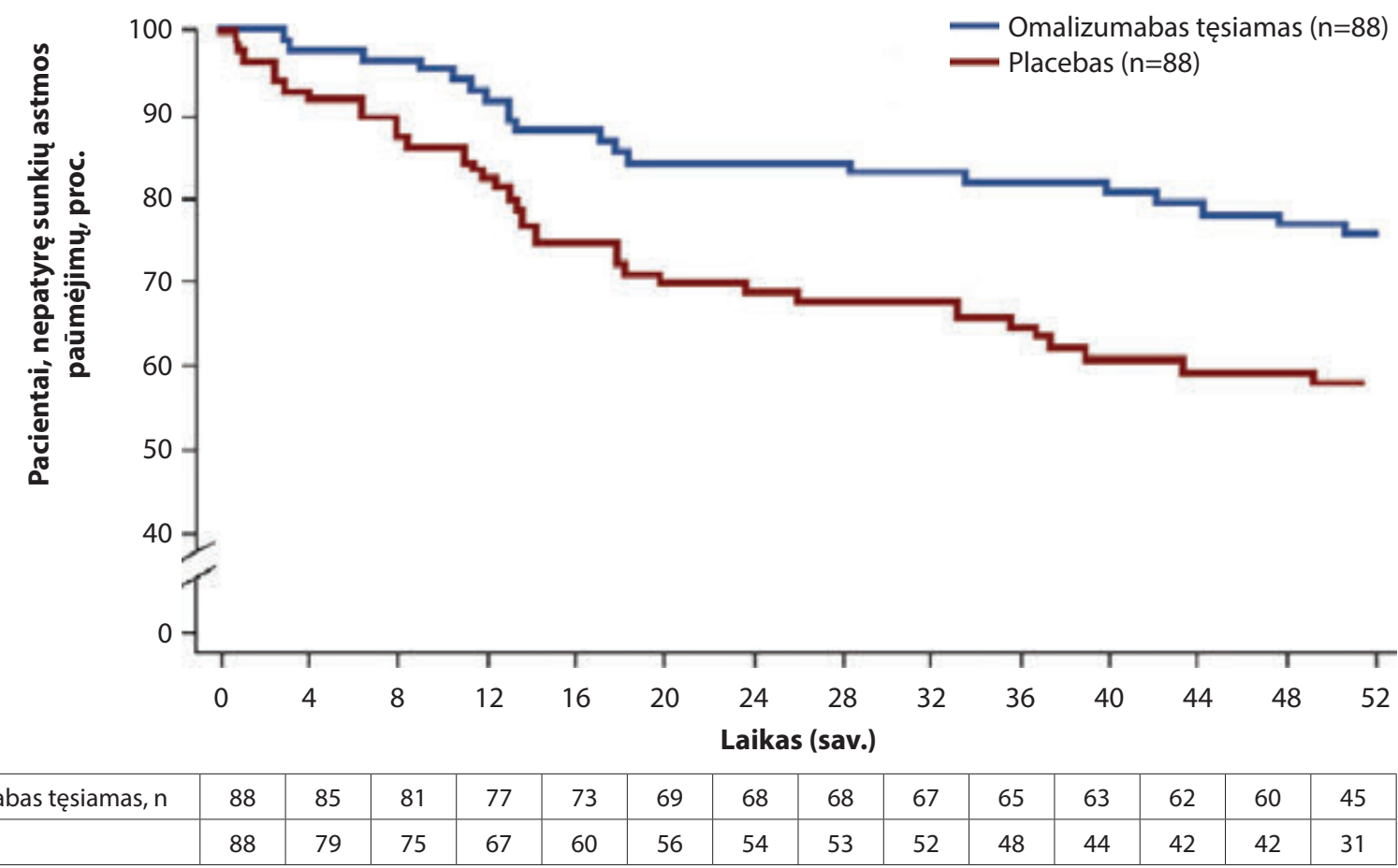

3 pav. Laikotarpis iki pirmo astmos paūmèjimo ilgesnis tęsiant gydymą omalizumabu 


\section{Farmakoterapija}

tinti omalizumabo veiksmingumą ir saugumą gydant vaikus (6-<12 metų), sergančius sunkia alergine astma. Tyrimas truko 52 savaites (24 savaites GKK dozè buvo stabili, o likusias 28 savaites buvo palaipsniui mažinama). I tyrimą įtraukti 246 pacientai (omalizumabo grupeje - 166, placebo grupèje - 80). Per 24 gydymo fiksuota GKK doze savaites, omalizumabas 34 proc. sumažino kliniškai reikšmingų paūmèjimų lyginant su placebu $(0,42$ palyginus su 0,$63 ; \mathrm{p}=0,047)$. Bendrai per 52 savaites paūmèjimų dažnis sumažejo 50 proc. $(\mathrm{p}<0,001)$. Omalizumabas pasižymejjo palankiu saugumu vaikams, o šalutinių poveikių dažnis nesiskyrè nuo placebo [19].

Omalizumabo veiksmingumas ir saugumas vaiku amžiuje įrodytas ne tik atsitiktinių imčių, bet ir klinikiniais tyrimais. Vienerių metų trukmès klinikinès praktikos tyrime tirti jaunesni nei 18 metų pacientai, kuriems patvirtinta sunki alerginè astma ir skirtas gydymas omalizumabu 2006-2009 m. Pacientai daugiau nei 12 mèn. stebèti tretinio lygio paslaugas teikiančiose sveikatos priežiūros ịstaigose. Tyrimo rezultatai parodè, kad, gydant omalizumabu, žymiai pagèrejo astmos kontrolè: gydymo pradžioje geros astmos kontrolès neturèjo nè vienas, astma buvo dalinai kontroliuojama 18 proc. ir nekontroliuojama 82 proc. tiriamųjų. Tyrimo pabaigoje atitinkamai - 67,25 ir 8 proc. $(\mathrm{p}<0,001)$. Astmos paūmèjimų dažnis sumažèjo 72 proc. (nuo 4,4 $(3,7-5,2)$ per praejjusius metus iki 1,25 $(0,55-1,95)$ gydymo metais $(\mathrm{p}<0,0001)$. Per metus IGK dozė sumažèjo 30 proc. $(-284-(-140) \mu \mathrm{g})$ [20].

Gydant omalizumabu vaikus sumažeja ir GGK dozè. Brodlie ir kt. atliktame klinikiniame tyrime dalyvavo 34 vaikai, sergantys sunkia astma ir vartojantys GGK (vidutinis amžius - 12 metų). Po 16 savičių gydymo omalizumabu prednizolono dozè sumažèjo nuo $20 \mathrm{iki}$ $5 \mathrm{mg}(\mathrm{n}=34, \mathrm{p}<0,0001$, itskaitant septynis vaikus, kurie visai nutraukè prednizolono vartojimą) [21].

\section{ANTI-IGE IR ANTI-IL-5}

Dažnai iškylantis klausimas, gydant sunkia alergine eozinofiline astma sergančius pacientus, kurị vaistą pasirinkti - imunoglobulino E antikūnus (anti-IgE) ar interleukino 5 antikūnus (anti-IL-5). Omalizumabas jungiasi išskirtinai prie cirkuliuojančio IgE ir neleidžia jam jungtis su FceRI (didelio afiniteto IgE receptoriumi) ant bazofilų ir putliųjų ląstelių paviršiaus, todèl sumažèja alerginę kaskadą galinčio sukelti laisvojo IgE kiekis. Taip blokuojamas uždegiminių žymenų išsiskyrimas iš putliụjų ląstelių ir sumažẻja uždegiminių ląstelių, ypač eozinofilų, pritraukimas ị kvẻpavimo takus [22-24].

Penkių atsitiktinių imčių klinikinių tyrimų, kuriuose dalyvavo sunkia alergine astma sergantys asmenys, gydyti omalizumabu, analizè parodè, kad omalizumabas buvo susijęs su reikšmingu periferinio kraujo eozinofilų kiekio sumažejimu [23]. Kitoje EXTRA studijoje $(n=850)$ buvo vertinama periferinio kraujo eozinofilu skaičiaus, kaip predikcinio veiksnio, vaidmuo gydymo omalizumabu veiksmingumui numatyti. Studijos rezultatai parodè, kad omalizumabas labiau sumažino astmos paūmèjimų skaičių tiems pacientams, kurių eozinofilų skaičius kraujyje buvo didesnis. Iškvėpto azoto monoksido frakcija (FeNO) ir didelis periostino kiekis taip pat buvo atsako i gydymą omalizumabu predikciniai veiksniai [25].

Pastarųjų metų klinikiniai tyrimai parodè, kad ilgalaikis gydymas anti-IgE reikšmingai sumažino kvèpavimo takų sienelès storị ir retikulinès bazinès membranos sustorejjimą ir šis poveis buvo nepriklausomas nuo eozinofilinès infiltracijos.

DREAM klinikinio tyrimo, kuriame buvo vertinamas mepolizumabo veiksmingumas gydant sunkią eozinofilinę astmą, duomenys parodè, kad IgE koncentracija ir atopija nebuvo susiję su atsaku mepolizumabui [22].

Apibendrinus mokslinius duomenis, pirmojo pasirinkimo pridètinis biologinès terapijos vaistas gydant sunkią alerginę eozinofilinę astmą turètų būti anti-IgE.

\section{APIBENDRINIMAS}

Omalizumabas yra veiksmingas pridetinis vaistas sunkiai alerginei astmai gydyti. Gydant omalizumabu, mažèja paūmèjimų dažnis, GGK ir IGK dozès, gèrejja astmos kontrolè ir gyvenimo kokybė. Ilgalaikis gydymas omalizumabu yra veiksmingas ir saugus, be to juo galima gydyti ir vaikus. Esant sunkiai alerginei eozinofilinei astmai, pirmojo pasirinkimo biologinè terapija turètų būti anti-IgE.

Straipsnis remiamas Novartis Pharma Services Inc. atstovybes

09/2017 B11709697558

\section{LITERATŨRA}

1. Biekšienė K, Malakauskas K, Danila E, Zablockis R, Blažienė A, Miliauskas S, ir kt. Lietuvos suaugusiujų sunkios astmos diagnostikos ir gydymo rekomendacijos 2017. Prieiga per internetą: http://www.pulmoalerg.lt.

2. Chung KF, Wenzel SE, Brozek JL, Bush A, Castro M, Sterk PJ, et al. International ERS/ATS guideliness on definition, evaluation and treatment of severe asthma. Eur Respir J. 2014; 43(2):343-73. Erratum in: Eur Respir J. 2014; 43(4):1216.

3. Global initiative for asthma. Global Strategy for Asthma Management and Prevention, Revised 2017. Available at: http:// www.ginasthma.com.

4. Hanania NA, Alpan O, Hamilos DL, Condemi JJ, ReyesRivera I, Zhu J, et al. Omalizumab in severe allergic asthma inadequately controlled with standard therapy: a randomized trial. Ann Intern Med. 2011; 154(9):573-82.

5. Bousquet J, Siergiejko Z, Swiebocka E, Humbert M, Rabe KF, Smith N, et al. Persistency of response to omalizumab therapy in severe allergic (IgE-mediated) asthma. Allergy. 2011; 66(5):671-8.

6. Humbert M, Beasley R, Ayres J, Slavin R, Hébert J, Bousquet J, et al. Benefits of omalizumab as add-on therapy in patients with severe persistent asthma who are inadequately controlled 


\section{Farmakoterapija}

despite best available therapy (GINA 2002 step 4 treatment) INNOVATE. Allergy. 2005; 60(3):309-16.

7. Ayres JG, Higgins B, Chilvers ER, Ayre G, Blogg M, Fox H. Efficacy and tolerability of anti-immunoglobulin E therapy with omalizumab in patients with poorly controlled (moderate-tosevere) allergic asthma. Allergy. 2004; 59(7):701-8.

8. Busse WW, Massanari M, Kianifard F, Geba GP. Effect of omalizumab on the need for rescue systemic corticosteroid treatment in patients with moderate-to-severe persistent IgEmediated allergic asthma: a pooled analysis. Curr Med Res Opin. 2007; 23(10):2379-86.

9. Vignola AM, Humbert M, Bousquet J, Boulet LP, Hedgecock $S$, Blogg $\mathbf{M}$, et al. Efficacy and tolerabilityy of antiimmunoglobulin $\mathrm{E}$ therapy with omalizumab in patients with concomitant allergic asthma and persistent allergic rhinitis: SOLAR. Allergy. 2004; 59(7):709-17.

10. Busse W, Corren J, Lanier BQ, cAlary M, Fowler-Taylor A Cioppa GD, et al. Omalizumab, anti-IgE recombinant humanized monoclonal antibody, for the treatment of severe allergic asthma. J Allergy Clin Immunol. 2001; 108(2):184-90.

11. Solèr M, Matz J, Townley R, Buhl R, O'Brien J, Fox H, et al. The anti-IgE antibody omalizumab reduces et al. exacerbations and steroid requirement in allergic asthmatics. Eur Respir J. $2001 ; 18(2): 254-61$

12. Holgate ST, Chuchalin AG, Hébert J, Lötvall J, Persson GB, Chung KF, et al. Efficacy and safety of a recombinant antiimmunoglobulin E antibody (omalizumab) in severe allergic asthma. Clin Exp Allergy. 2004; 34(4):632-8.

13. D'Amato G, Salzillo A, Piccolo A, D>Amato M, Liccardi G. A review of anti-IgE monoclonal antibody (omalizumab) as add on therapy for severe allergic (IgE-mediated) asthma. Ther Clin Risk Manag. 2007; 3(4):613-9.

14. Siergiejko Z, Świebocka E, Smith N, Peckitt C, Leo J, Peachey G, et al. Oral corticosteroid sparing with omalizumab in severe allergic (IgE-mediated) asthma patients. Curr Med Res Opin. 2011; 27(11):2223-8.

15. Rodrigo GJ, Neffen H, Castro-Rodriguez JA. Efficacy and safety of subcutaneous omalizumab vs placebo as add-on therapy to corticosteroids for children and adults with asthma. Chest. 2011; 139(1):28-35.

16. Mansur AH, Srivastava S, Mitchell V, Sullivan J, Kasujee I. Longterm clinical outcomes of omalizumab therapy in severe allergic asthma: Study of efficacy and safety. Respir Med. 2017; 124(1):36-43.

17. Ledford D, Busse W, Trzaskoma B, Omachi TA, Rosén K Chipps BE, et al. A randomized multicenter study evaluating Xolair persistence of response after long-term therapy. J Allergy Clin Immunol. 2017; 140(1):162-9.

18. Long AA, Fish JE, Rahmaoui A, Miller MK, Bradley MS Taki HN, et al. Baseline characteristics of patients enrolled in EXCELS: a cohort study. Ann Allergy Asthma Immunol. 2009; 103(3):212-9.

19. Kulus M, Hébert J, Garcia E, Fowler Taylor A, Fernandez Vidaurre C, Blogg M. Omalizumab in children with inadequately controlled severe allergic (IgE-mediated) asthma. Curr Med Res Opin. 2010; 26(6):1285-93.

20. Deschildre A, Marguet C, Salleron J, Pin I, Rittié JL, Derelle J, et al. Add-on omalizumab in children with severe allergic asthma: a 1-year real life survey. Eur Respir J. 2013; 42(5):1224-33.

21. Brodlie M, McKean MC, Moss S, Spencer DA. The oral corticosteroid-sparing effect of omalizumab in children with severe asthma. BMJ. 2012; 97(7):606-9.

22. Papathanassiou E, Loukides S, Bakakos P. Severe asthma: anti-IgE or anti-IL-5? Eur Clin Respir J. 2016; 3:31813.

23. Massanari $M$, Holgate $S T$, Busse WW, Jimenez $P, \mathbf{K i}$ anifard F, Zeldin R. Effect of omalizumab on peripheral blood eosinophilia in allergic asthma. Respir Med. 2010 104(2):188-96.

24. Yalcin AD. An overview of the effects of anti-IgE therapies. Med Sci Monit. 2014; 20:1691-9.

25. Hanania NA, Wenzel S, Rosen $K$, Hsieh HJ, Mosesova S Choy DF, et al. Exploring the effects of omalizumab in allergic asthma: an analysis of biomarkers in the EXTRA study. Am J Respir Crit Care Med. 2013; 187(8):804-11. 